\title{
Altitudinal clines for cyanogenesis in introduced populations of white clover near Vancouver, Canada
}

\author{
Fred R. Ganders
}

\begin{abstract}
Department of Botany, University of British Columbia,
\end{abstract} Vancouver, B.C., Canada V6T 2B1.

Frequencies of cyanogenic and acyanogenic plants were determined in 15 populations of white clover, Trifolium repens, representing altitudinal comparisons at five localities in southwestern British Columbia, Canada and one in northwestern Washington State, U.S.A. The percentage of cyanogenic plants averaged $53 \cdot 8$ per cent in low elevation $(<100 \mathrm{~m})$ populations, 25.7 per cent in mid elevation $(500-650 \mathrm{~m})$ populations, and 11.6 per cent in high elevation (1000-1500 m) populations. At all of the localities except Grouse Mountain, North Vancouver, B.C., the frequency of cyanogenic plants was lowest in high elevation populations. The altitudinal ratio-cline for cyanogenesis parallels clines found in the Swiss Alps and Wales, where white clover is a native species. White clover is introduced in North America, and the cline in southwestern British Columbia must have been established in less than a century, and in some populations less than 15 years. This pattern is consistent with the hypothesis of strong selective pressure for alternative phenotypes by temperature and/or predation by slugs and snails.

\section{INTRODUCTION}

Cyanogenesis in white clover is a textbook example of natural selection in plants. Many populations of white clover, Trifolium repens L., are polymorphic for cyanogenesis, the release of $\mathrm{HCN}$ from damaged leaf tissue. Cyanide production is dependent on the presence of the dominant allele at the Ac locus for the production of the cyanogenic glucosides lotaustralin and linamarin, and the dominant allele at the $L i$ locus for their hydrolysing enzyme linamarase. The two loci are unlinked. Plants with genotypes which are homozygous recessive at either locus do not release significant amounts of cyanide (Melville and Doak, 1940; Coop, 1940; Corkill, 1942; Atwood and Sullivan, 1943).

Daday (1954a) found that the frequency of cyanogenic plants in populations of white clover in Europe, where it is a native species, varied from $0-100$ per cent. Dominant allele frequencies at both the $A c$ and $L i$ loci show a geographical ratio-cline, increasing with increasing mean January temperature. Daday (1954b) also found that six populations ranging from $580-1950 \mathrm{~m}$ elevation in the Swiss Alps showed a corresponding ratio-cline at both loci, with the dominant alleles decreasing with increasing altitude. Daday (1954a, b, 1965) maintained that temperature itself was the major selective factor determining allele frequencies at these loci, and found some evidence for different performance by cyanogenic and acyanogenic plants at different temperatures in greenhouse and garden experiments.

Jones (1962, 1966) experimentally demonstrated selective herbivory by slugs and snails on acyanogenic plants of Lotus corniculatus L., another legume species which exhibits a similar polymorphism. He postulated that the clines in white clover were controlled by herbivores. He suggested that temperature acted partly indirectly by controlling the distribution and abundance of slugs and snails, thus accounting for the temperature correlation of the cline. Cold temperature could presumably select directly against cyanogenesis where herbivores were rarer.

Both postulated selective pressures should result in selection for similar clines in areas where white clover is an introduced species, if similar herbivores and temperature ranges occur. Somewhat surprisingly this interesting problem has received little further study. If temperature and selective grazing by gastropods are responsible for clines in cyanogenesis frequency in white clover, 
altitudinal clines for cyanogenesis frequency should evolve in southwestern British Columbia and western Washington State. Both white clover and introduced European slugs and snails are common naturalised species in this region. White clover has been introduced into British Columbia as a weed, as a pasture legume, and as a component of lawn seed mixtures. White clover now occurs in disturbed areas such as roadsides and waste land, as well as in lawns and pastures, from sea level to timberline on mountains, so that temperature gradients exist. Introduced slugs and snails are most common at low elevations, as are native species of slugs. I have observed slugs eating white clover plants on numerous occasions. To test whether altitudinal clines for cyanogenesis have evolved, I determined frequencies of cyanogenic plants in 15 populations of white clover at low, mid and high elevations in the mountains of southwestern British Columbia and adjacent Washington State.

\section{MATERIALS AND METHODS}

Cuttings from individual clover plants were collected from populations at five localities near Vancouver in southwestern British Columbia and at Mt. Baker in adjacent Washington State. In most cases the populations which were sampled were along roads to ski areas. Sample sizes ranged from 162 to 210 per population (table 1). Low elevation populations occurred at less than $100 \mathrm{~m}$ altitude, mid elevation populations were between 500 and $650 \mathrm{~m}$, and high elevation populations were 1000 to $1500 \mathrm{~m}$ in altitude. Lowest and highest populations at each locality were less than
$5 \mathrm{~km}$ apart, except at Mt. Seymour where they were within $8 \mathrm{~km}$, and at Mt. Baker, where they were within $10 \mathrm{~km}$. Cuttings were kept refrigerated in plastic bags and leaves tested for cyanide production within $48 \mathrm{~h}$. Cyanogenic phenotypes were determined by standard sodium picrate paper tests (Corkill, 1940). In the initial collections, from Cypress Park, material was divided, and glucoside (amygdalin) or enzyme ( $\beta$-glucosidase) added to test whether $A c$ or $L i$ alleles were present in acyanogenic plants. Both loci were polymorphic in all three populations, but because genotype frequencies could not be estimated without extensive progeny testing, this was not pursued. Genotype frequencies given in Daday (1954b) were calculated from Hardy-Weinberg equilibrium assumptions, and are probably invalid because his evidence indicated that selection was likely.

\section{RESULTS}

Except at Grouse Mtn. and Hemlock Mtn., there was a significantly lower percentage of cyanogenic plants at higher elevations (table 1). The overall trend is especially clear when the data are averaged by elevation class. The frequency of cyanogenic plants decreased from 54 per cent at low elevations, to 26 per cent at mid elevations, to 12 per cent at high elevations. The differences are very highly significant $\left(\chi_{[2]}^{2}=393 \cdot 9, G\right.$ statistic $=390 \cdot 8, P<$ $0.0001)$. The altitudinal clines in cyanogenic frequencies in the mountains surrounding Vancouver, where white clover is introduced, parallel those found in the Swiss Alps (Daday, 1954b) and north Wales (Araújo, 1976) where it is native.

Table 1 Percentage of cyanogenic plants (genotype $A c--L i--$ ) in populations of white clover at different elevations in southwestern British Columbia and adjacent Washington

\begin{tabular}{|c|c|c|c|c|c|c|}
\hline \multirow[b]{3}{*}{ Locality } & \multicolumn{6}{|c|}{ Elevation } \\
\hline & \multicolumn{2}{|l|}{ Low } & \multicolumn{2}{|l|}{ Mid } & \multicolumn{2}{|l|}{ High } \\
\hline & $A c L i$ & $N$ & $A c L i$ & $N$ & $A c L i$ & $N$ \\
\hline Cypress Park & $60 \cdot 5$ & 177 & $16 \cdot 8$ & 200 & $13 \cdot 0$ & 100 \\
\hline Grouse Mtn. & $15 \cdot 0$ & 200 & & & $31 \cdot 5$ & 200 \\
\hline Hemlock Mtn. & & & $14 \cdot 4$ & 202 & $13 \cdot 5$ & 200 \\
\hline Mt. Baker, WA & $64 \cdot 2$ & 190 & $22 \cdot 0$ & 200 & $5 \cdot 3$ & 190 \\
\hline Mt. Seymour & $80 \cdot 0$ & 175 & $70 \cdot 4$ & 162 & $5 \cdot 1$ & 200 \\
\hline Whistler Mtn. & & & $13 \cdot 8$ & 210 & $1 \cdot 1$ & 190 \\
\hline Total & $53 \cdot 8$ & 742 & $25 \cdot 7$ & 964 & $11 \cdot 6$ & 1080 \\
\hline
\end{tabular}




\section{DISCUSSION}

There are several reasons why the cyanogenesis polymorphism in white clover is not likely to be controlled by only one selective factor. For one thing, polymorphic populations range over a huge geographical area, in the native and introduced range of the species. This range covers habitats with a wide variety of ecological conditions. The distances are too large for gene flow to be maintaining the polymorphism in a clinal pattern. Second, the cyanogenic phenotype requires specific alleles at two unlinked loci. Some selective forces may influence allele frequencies by acting on each locus independently. Ennos (1981) presented evidence that some selective regimes can select at the $\mathrm{Li}$ locus but not the Ac locus. Therefore, the factors controlling frequencies in these polymorphic populations are not likely to be simple. At least two and probably more selective forces must be operating on the polymorphism.

Most recent investigations of the cyanogenesis polymorphism in white clover have focussed on the selective factors themselves. There is conclusive evidence that herbivory by slugs and snails, and perhaps aphids, selects against the acyanogenic phenotype (Angseesing, 1974; Angseesing and Angseesing, 1973; Crawford-Sidebotham, 1972; Dirzo and Harper, 1982a; Dritschilo et al., 1979; Horrill and Richards, 1986; Jones, 1962, 1966). The evidence for other factors, such as temperature (Daday, 1965), and soil moisture stress (Foulds, 1977; Foulds and Grime, 1972a, $b$; Foulds and Young, 1977) is neither very numerous nor very conclusive (see also Dirzo and Harper, 1982b), and sample sizes in experiments were often small.

Despite how these selective factors interact, they are supposed to produce clines in which the cyanogenic phenotype decreases with altitude. Somewhat surprisingly, the generality of this hypothesis has been little tested. Daday (1954b) found a cline from 580 to $1950 \mathrm{~m}$ elevation in the Alps, and Araújo (1976) found one from 30 to $490 \mathrm{~m}$ elevation in Wales. I predicted that in British Columbia altitudinal clines for cyanogenesis should also develop in introduced populations of white clover. The results confirm that altitudinal clines for cyanogenesis in white clover have evolved quickly in introduced populations where temperature ranges and herbivore faunas are similar to those found in the native range of the species. These clines must have evolved in less than a century, and in some cases in less than two decades, because the roadside habitats are that recent. At the high and mid elevation sites at Cypress Park, white clover was introduced in a seed mixture with grasses about 10 years previously, but immigration of seeds from weedy roadside populations is also possible. None of the sites were near agricultural areas, so that the clover in all sites was probably derived from weedy or lawn strains rather than pasture strains. I think that this is strong confirmation that the ratio-clines for cyanogenesis correlated with temperature are the result of natural selection. However, in the area I studied, altitude is causally correlated with many factors besides temperature, including length of growing season, snow cover, rainfall, soil moisture, cloud cover, and flora and fauna. The three main selective factors which have been postulated to affect the cyanogenesis polymorphism are herbivores, temperature, and soil moisture stress. In British Columbia, gastropods, which select for cyanogenic plants, decrease with altitude, and may be less frequent in areas with moisture stress. Moisture stress, which may select for acyanogenic plants, also decreases with altitude. Temperature decreases with altitude, and low temperature may select for acyanogenesis. So one might expect that at low elevations slugs select for cyanogenic phenotypes and moisture stress selects for acyanogenic phenotypes, at high elevations cold selects for acyanogenic phenotypes. All three of these factors have gradients which are correlated to some extent. It is not going to be possible to explain the clinal patterns observed on the basis of a single factor, and more complex theoretical models are needed.

Acknowledgements Patrick Zaidel, Andrew H. Yu, and Sharon Y.C. Fong provided able field and laboratory assistance. Grants from the Natural Sciences and Engineering Research Council of Canada and the Province of British Columbia Careers 87 Programme provided financial support.

\section{REFERENCES}

ANGSEESING, J. P. A. 1974. Selective eating of the acyanogenic form of Trifolium repens. Heredity, 32, 73-83.

ANGSEESING, J. P. A. AND ANGSEESING, w. J. 1973. Field observations on the cyanogenesis polymorphism in Trifolium repens. Heredity, 31, 276-282.

ARAÚJO, A. M. DE. 1976. The relationship between altitude and cyanogenesis in white clover (Trifolium repens L.). Heredity, 37, 291-293.

ATwOOD, S. S. AND Sullivan, J. T. 1943. Inheritance of a cyanogenetic glucoside and its hydrolysing enzyme in Trifolium repens. J. Hered., 34, 311-320.

COOP, I. E. 1940. Cyanogenesis in white clover (Trifolium repens L.). III. A study of linamarase, the enzyme which hydrolyses lotaustralin. N.Z. J. Sci. Tech., 22, 71B-83B. 
CORKıLL, L. 1940. Cyanogenesis in white clover (Trifolium repens L.). I. Cyanogenesis in single plants. N.Z. J. Sci. Tech. B, 22, 65-67.

CORKILL, L. 1942. Cyanogenesis in white clover (Trifolium repens L.). V. The inheritance of cyanogenesis. N.Z. J. Sci. Tech. B, 23, 178-193.

CRAWFORD-SIDEBOTHAM, T. J. 1972. The role of slugs and snails in the maintenance of the cyanogenesis polymorphisms of Lotus corniculatus and Trifolium repens. Heredity, $28,405-411$.

DADAY, H. 1954a. Gene frequencies in wild populations of Trifolium repens L. I. Distribution by latitude. Heredity, 8 , $61-78$.

DADAY, H. 1954b. Gene frequencies in wild populations of Trifolium repens L. II. Distribution by altitude. Heredity, 8, 377-384.

DADAY, H. 1965. Gene frequencies in wild populations of Trifolium repens L. IV. Mechanism of natural selection. Heredity, 20, 355-365.

DIRZO, R. AND HARPER, J. L. $1982 a$. Experimental studies on slug-plant interactions. III. Differences in the acceptability of individual plants of Trifolium repens to slugs and snails. J. Ecol., 70, 101-117.

DIRZO, R. AND HARPER, J. L. 1982b. Experimental studies on slug-plant interactions. IV. The performance of cyanogenic and acyanogenic morphs of Trifolium repens in the field. J. Ecol., 70, 119-138.

DRITSCHILO, W., KRUMMEL, J., NAFUS, D. AND PIMENTEL, D. 1979. Herbivorous insects colonising cyanogenic and acyanogenic Trifolium repens. Heredity, 42, 49-56.

ENNOS, R. A. 1981. Detection of selection in populations of white clover (Trifolium repens L.) Biol. J. Linn. Soc, 15, $75-82$.
FOULDS, w. 1977. The physiological response to moisture supply of cyanogenic and acyanogenic phenotypes of Trifolium repens L. and Lotus corniculatus L. Heredity, 39, 219-234.

FOULDS, W. AND GRIME, J. P. 1972a. The influence of soil moisture on the frequency of cyanogenic plants in populations of Trifolium repens and Lotus corniculatus. Heredity, $28,143-146$.

FOULDS, W. AND GRIME, J. P. 1972b. The response of cyanogenic and acyanogenic phenotypes of Trifolium repens to moisture supply. Heredity, 28, 181-187.

FOULDS, W. AND YOUNG, L. 1977. Effect of frosting, moisture stress and potassium cyanide on the metabolism of cyanogenic and acyanogenic phenotypes of Lotus corniculatus L. and Trifolium repens L. Heredity, 38, 19-24.

HORRILL, J. C. AND RICHARDS, A. J. 1986. Differential grazing by the mollusc Arion hortensis Fér. on cyanogenic and acyanogenic seedlings of the white clover, Trifolium repens L. Heredity, 56, 277-281.

JONES, D. A. 1962. Selective eating of the acyanogenic form of the plant Lotus corniculatus L., by various animals. Nature, 193, 1109-1110.

JONES, D. A. 1966. On the polymorphism of cyanogenesis in Lotus corniculatus. I. Selection by animals. Can. J. Genet. Cytol., 8, 556-567.

MELVILLE, F. AND DOAK, B. W. 1940. Cyanogenesis in white clover (Trifolium repens L.). II. Isolation of the glucosidal constituents. N.Z. J. Sci. Tech. B, 22, 67-71. 